\title{
PENINGKATAN KUALITAS PELATIHAN DI TRAINING CENTRE MELALUI INTEGRASI METODE SERVICE QUALITY (SERQUAL) DAN QUALITY FUNCTION DEPLOYMENT (QFD) Study Kasus pada PT. XYZ
}

\author{
Puri Ayu Margareta*), Hana Catur Wahyuni \\ Prodi Teknik Industri Fakultas Teknik Universitas Muhammdiyah Sidoarjo \\ Jl. Raya Gelam 250, Candi, Sidoarjo
}

(Received: August, 182016 / Accepted: December 21, 2016

\begin{abstract}
ABSTRAK
Adanya peningkatan persaingan dalam industri jasa menyebabkan industri jasa berlomba-lomba dalam meningkatkan kualitas layanan untuk kepuasan kepada konsumennya. Secara sederhana, kepuasan adalah perasaan seseorang dimana persepsinya terhadap suatu produk atau jasa tertentu telah sesuai dengan harapannya. Jika persepsi terhadap suatu produk atau jasa tadi melebihi apa yang diharapkan tentu saja konsumen puas akan tetapi jika sebaliknya, konsumen akan merasa tidak puas.

Training Centre merupakan tempat pelatihan skilldi sebuah perusahaan sepatu. Dan untuk menganalisa dan meningkatkan kepuasan karyawan dalam pelatihan tersebut, serta memberikan usulan perbaikan atribut dan respon teknis pelayanan maka dapat menggunakan metode integrasi Service Quality dan Quality Function Deployment

Berdasarkan rumah kualitas dan analisanya didapatkan kualitas layanan Training Centre masih kurang memuaskan jika dibandingkan dengan apa yang diharapkan oleh karyawan. Sesuai analisa prioritas kebutuhan pelanggan berdasarkan nilai raw weight, nilai kepentingan, maka diketahui atribut-atribut yang perlu diperhatikan berdasarkan 3 ( tiga ) prioritas utama adalah Kondisi mesin untuk latihan skill baik dengan nilai prioritas raw weight $(8,932)$, Jumlah mesin memadai dalam pelatihan dengan nilai prioritas raw weight ( 8,886), Kesigapan seluruh trainermembantu trainee setiap waktu dengan nilai prioritas raw weight ( 7,937 ). Prioritas pelayanan yang membutuhkan perhatian lebih dari pihak perusahaan untuk segera diperbaiki berdasarkan 3 ( tiga ) prioritas respon teknis adalah Melakukan pengawasan keseluruhan pelatihan dengan nilai ( 0,184), Meningkatkan keahlian trainer dalam program pelatihan dengan nilai $(0,137)$, Penambahan fasilitas-fasilitas dengan nilai ( 0,129$)$.
\end{abstract}

Kata kunci : kepuasan konsumen; QFD; servqual;training centre

\begin{abstract}
There is an increasing competition in service industries, causing the service industry are competing in improving service quality to satisfaction to customers. In simple terms, satisfaction is a feeling or state of a person in which perceptions of a particular product or service in accordance with expectations. If the perception of a product or service was beyond what was expected of course, consumers are satisfied but if otherwise, consumers will feel dissatisfied.

Training Centre is venue training skill in the shoe company. To analyse and improve employee satisfaction in the training, then provide technical service and response attributes, then using integration methods Servqual and Quality Function Deployment.

Based on the analysis found the house of quality and service quality Training Centre still less satisfactory when compared with what is expected by its employee. Appropriate analysis of the priority needs of the customer based on raw weight value, the value of the interest, then unknown attributes to be considered
\end{abstract}

\footnotetext{
${ }^{*}$ Penulis Korespondensi.

email: Poery_ayuMar@yahoo.com
} 
on the terms of 3 (three) top priority is condition of machines is good a priority value raw weight (8.932), a sufficient number of machine with a priority value raw weight (8.886), alacrity all trainer in helping trainees every time with a priority value raw weight (7.937). Priority services desperately need more attention from the company to immediately repaired by 3 (three) priority technical response is to supervise the overall training with the value (0.184), improve skills trainers in the training program with the value (0.137), additional facilities with a value of (0.129).

Keywords: consumer satisfaction; QFD; servqual; training centre

\section{Pendahuluan}

Perkembangan dalam dunia usaha yang maju dengan pesat saat ini mendorong perusahaanperusahaan di Indonesia harus siap menghadapi persaingan global. Dunia usaha yang sangat kompetitif ini, perusahaan dituntut untuk menghasilkan produk yang memiliki nilai kualitas terbaik, efisiensi biaya produksi serta pengiriman yang tepat waktu. Semua ini dimaksudkan agar perusahaan dapat tetap menjamin kelangsungan hidup perusahaan dan organisasi yang mendiaminya.

Dengan kondisi tingkat persaingan yang semakin ketat seperti saat ini perusahaan harus berupaya memiliki tingkat kualitas yang baik. Salah satu upaya yang dapat dilakukan dalam meningkatkan dan menjaga kualitas adalah dengan melaksanakan jasa pelatihan karyawan yang berguna untuk menambah keahlian dan pengetahuan dalam mendukung produktifitas perusahaan serta produk yang diproduksi.

Pelatihan merupakan kegiatan jasa di dalam perusahaan yang dimaksudkan untuk memperbaiki dan mengembangkan sikap, tingkah laku, keahlian dan pengetahuan karyawan untuk mendapatkan produk yang berkualitas sesuai dengan standar dari perusahaan yang bersangkutan. Apabila pelatihan dilaksanakan dengan baik dan karyawan mempraktekkannya di dalam lingkungan kerja, maka kualitas produksi akan semakin meningkat. Untuk itu perlu diberikan pelatihan yang lebih efektif dan efisien di dalam pengembangan kualitas dan keterampilan pegawai.

Training Centre adalah salah satu jasa pelatihan yang dimiliki oleh pabrik sepatu yang berada di kawasan Jawa Timur. Tujuan dari perusahaan tersebut mengadakan layanan dalam bentuk jasa pelatihan adalah untuk proses pengembangan karyawan dalam meningkatkan mutu dan keahlian, serta menciptakan pola pikir yang sama dalam meningkatkan kualitas produksi. Namun, seiring dengan banyaknya karyawan yang menulis melalui feedback pelatihan tentang keluhan mengenai kurangnya pelayanan dan prasarana yang diberikan oleh Training Centre, mengindikasikan adanya ketidakpuasan karyawan terhadap kinerja jasa pelatihan tersebut. Oleh sebab itu untuk mengatasi hal tersebut maka perlu diadakan pengukuran tingkat kepuasan konsumen (karyawan) agar segera diketahui atribut apa yang bisa membuat karyawan tidak puas dan sesegera mungkin diperbaiki. Dan servqual merupakan metode yang tepat karena berguna untuk menganalisis kesesuaian antara persepsi dan harapan karyawan atau trainee sebagai pengguna jasa terhadap kualitas layanan yang diberikan oleh pihak Training Centre dan dapat diteruskan dalam metode $Q F D$ untuk memperoleh respon teknis yang harus dilakukan untuk mengatasi kesenjangan kualitas prioritas utama yang ditemui dalam metode servqual.Tujuan dari penelitian ini adalah untuk mengidentifikasi atribut tertinggi kualitas pelayanan jasa di Training Centre, mengidentifikasi gap terbesar antara persepsi dan harapan terhadap jasa pelayanan pelatihan yang diberikan di Training Centre serta merancang perbaikan sistem kualitas layanan di Training Centre.

\section{Tinjauan Pustaka}

Menurut Parasuraman, Berry, dan Zeithaml dalam Ginting, Halim (2012), lima hal utama dimensi-dimensi service quality tersebut antara lain:

1. Kehandalan (Reliability), yakni kemampuan perusahaan atau service provider untuk memenuhi janjinya kepada pelanggan.

2. Daya tanggap (responsiveness), yaitu keinginan provider untuk membantu customer dengan penyediaan layanan secara tepat.

3. Jaminan (assurance), yaitu pengetahuan dan keramahan dari para karyawan haruslah sebaik kemampuan mereka untuk menanamkan kepercayaan kepada pelanggan.

4. Empati, yang perhatian individu terhadap pelanggan.

5. Bukti langsung (Tangibles), yang tampilan atau fasilitas fisik yang dimiliki oleh service provider.

Konsep serqual digunakan untuk menghitung gap antara persepsi konsensus terhadap jasa dan nilai ekspektasi atau harapan. Berikut adalah persamaannya (Wijaya, Tony, 2011) :

$\mathrm{Q}=\mathrm{P}($ Perceived service $)-\mathrm{E}($ Expected service $)$

Keterangan :

$\mathrm{Q}=$ Kualitas pelayanan $($ Quality Of Sevice $)$

$\mathrm{P}=$ Persepsi akan pelayanan (Perceived service)

$\mathrm{E}=$ Harapan akan layanan (Expected service)

Lebih dari itu, Wijaya, Tony (2011) menyebutkan kepuasan pelanggan yang mengacu pada kelima dimensi yang disebutkan di atas, maka organisasi dapat menentukan jawaban atau hambatan yang 
mungkin muncul dalam melaksanakan pelayanan yang berkualitas sesuai harapan pelanggan.

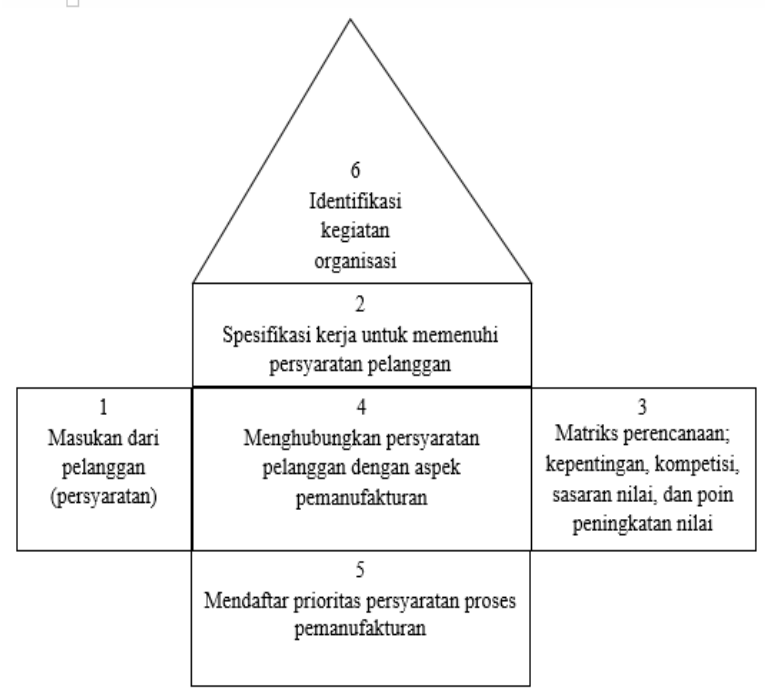

Gambar 1. Matriks House of Quality

Sedangkan QFD (Quality Function Deployment) adalah metode perencanaan dan pembangunan produk/jasa secara terstruktur yang memungkinkan tim pengembang mendefinisikan secara jelas kebutuhan dan harapan konsumen dan mengevaluasi kemampuan produk/jasa secara sistematik untuk memenuhi kebutuhan dan harapan tersebut (Cohen dalam Imron, 2014).

Struktur QFD adalah House of Quality yaitu matriks yang berbentuk rumah seperti gambar 2.3, yang terdiri atas enam komponen seperti bentuk rumah. Penelitian ini bertujuan mendapatkan gap antar tingkat kepentingan dan kepuasan, serta mengidentifikasi aspek-aspek kualitas layanan yang perlu dilakukan pengembangan oleh perusahaan. (Bounds dalam Ginting, Halim, 2013)

Tahap- Tahap Untuk Menyusun Rumah Kualitas Tahap I : Matrik Kebutuhan Pelanggan

Tahap ini meliputi kegiatan :

- Memutuskan siapa pelanggannya

- Mengumpulkan data kualitatif berupa keinginan dan kebutuhan pelanggan. Metode ini dilakukan dengan wawancara (Contextual Inguery) pada pelanggan.

- Menyusun kebutuhan tersebut.

Tahap II : Matrik Perencanaan

Tahap ini bertujuan :

- Mengukur kebutuhan-kebutuhan pelanggan.

- Menentukan tujuan-tujuan performansi kepuasan.

Tahap III : Respon Teknis

Tahap ini merupakan transformasi dari kebutuhankebutuhan yang bersifat non teknis menjadi data yang bersifat teknis guna memenuhi kebutuhan-kebutuhan tersebut.
Tahap IV : Menentukan Hubungan Respon Teknis dengan Kebutuhan Pelanggan

Tahap ini menentukan seberapa kuat hubungan antara respon teknis (tahap III) dengan kebutuhankebutuhan pelanggannya (tahap I). hubungan antara keduanya dapat berupa hubungan yang sangat kuat atau tidak ada korelasi antara keduanya.

Tahap V : Korelasi Teknis

Tahap ini menetapkan hubungan dan ketergantungan antara karakteristik kualitas pengganti atau respon teknis.

Tahap VI : Benchmarking dan Penetapan Target

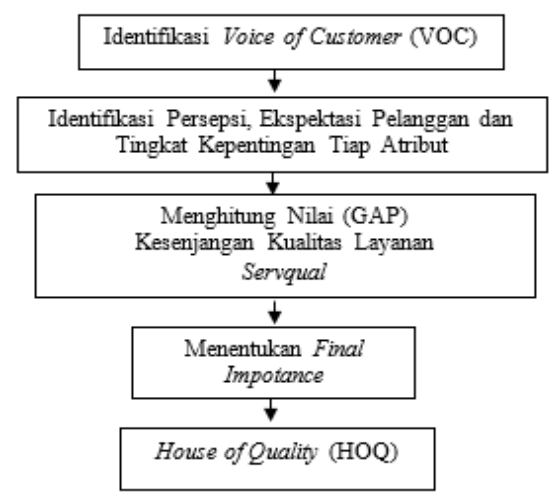

Gambar 2. Integrasi Servqual dan QFD

Benchmarking adalah sebuah cara sistematis untuk mengidentifikasi, memahami, dan secara kreatif menciptakan pengembangan produk, jasa, desain peralatan, proses dan diterapkan untuk meningkatkan performansi suatu organisasi.

Pengintegrasian konsep service quality (servqual) ke dalam quality function deployment (QFD) dapat dilihat pada gambar 2.4. QFD bertindak sebagai proses perencanaan untuk menerjemahkan kebutuhan pelanggan, yaitu meliputi persepsi dan harapan pelanggan, sehingga akan bisa mengidentifikasi gap kesenjangan kualitas layanan servqual.

\section{Metodologi Penelitian}

Pengambilan data dilaksanakan di Training Centre pada perusahaan sepatu di wilayah Jawa Timur. Sedangkan, yang menjadi responden adalah karyawan yang pernah mengikuti pelatihan pada tahun 2014. Pegambilan data penelitian dilakukan dengan menggunakan metode:

1. Interview ( wawancara )

Yaitu suatu teknik pengumpulan data yang di peroleh dengan jalan melakukan wawancara terhadap karyawan yang pernah mengikuti pelatihan di Training Centre.

2. Observasi ( pengamatan)

Yaitu suatu teknik pengumpulan data yang di peroleh dengan jalan melakukan pengamatan dan 
pencatatan secara langsung pada obyek yang di teliti.

3. Dokumentasi.

Yaitu suatu teknik pengambilan data, gambar, atau isi dari buku, jurnal dan internet untuk referensi.

4. Studi Pustaka

Yaitu metode pengumpulan data dari buku-buku literatur yang berhubungan dengan masalahmasalah yang dibahas.

5. Penyebaran Angket

Metode pengumpulan data yang dilakukan dengan penyebaran angket atau kuesioner kepada responden yang diharapkan akan mendapatkan jawaban seperti yang diinginkan serta merespon keluhan ataupun masukan dari responden.

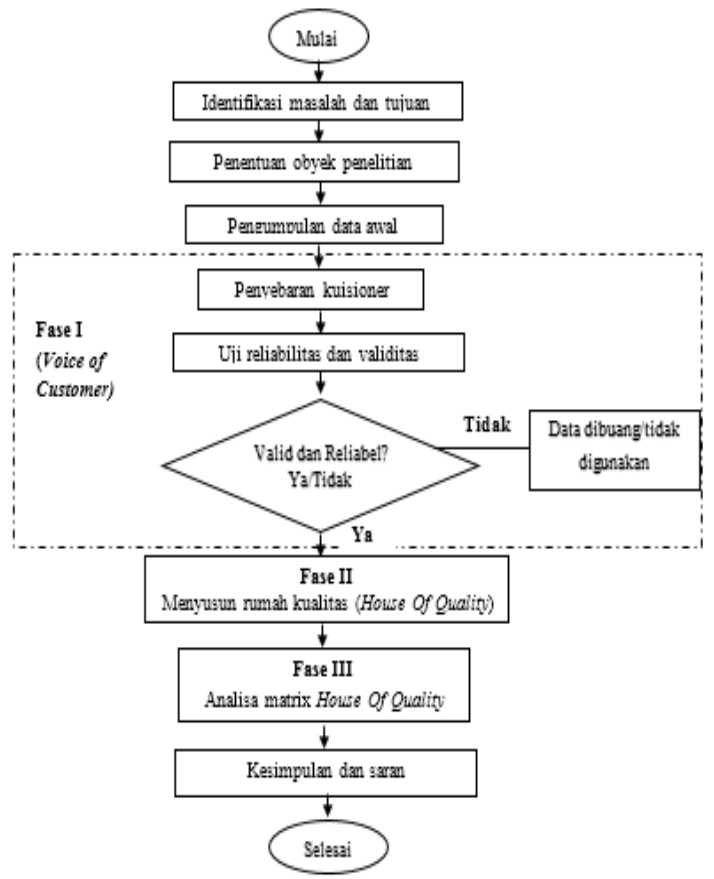

Dan berikut ini adalah diagram alir penelitian yang digunakan oleh peneliti :

\section{Hasil Dan Pembahasan}

Sebelum kuesioner formal disebarkan, maka lebih dahulu dilakukan penyebaran kuesioner awal (pre sampling) sebanyak 30 kuesioner. Tujuan dilakukan penyebaran kuesioner awal (pre sampling) adalah untuk mengetahui bahwa kuesioner sudah dimengerti dengan baik oleh responden (konsumen). Dari 30 kuesioner awal (pre sampling) yang disebarkan, terdapat 28 kuesioner yang diisi dengan benar, sedangkan 2 kuesioner dianggap tidak valid. Maka, untuk menghitung jumlah sampel yang diperlukan untuk menyebarkan kuesioner secara formal digunakan rumus Bernoulli sebagai berikut (Wahyuni,dkk, 2015) :

$$
N \geq \frac{\left(z^{\alpha_{d}}\right)^{2} p q}{a^{2}}
$$

Sehingga, jumlah sampling yang digunakan untuk menyebar kuesioner sebanyak :

$$
\begin{aligned}
N=\frac{\left(z^{\alpha} / 2\right)^{2} p x q}{e^{2}} & =\frac{(1,96)^{2}\left(\frac{28}{\mathrm{a} 0}\right)\left(\frac{2}{\mathrm{a} 0}\right)}{(0,05)^{2}}=95,5=96 \\
N & \geq 96
\end{aligned}
$$

dimana :

$\mathrm{N}=$ jumlah sampel minimum

$\mathrm{Z}=$ Nilai distribusi normal

$\alpha=$ Taraf signifikansi $(0,95)$

$\mathrm{e}=$ Tingkat kesalahan $(0,5)$

$\mathrm{p}=$ proporsi jumlah kuesioner yang dianggap benar $\mathrm{q}=$ proporsi jumlah kuesioner yang dianggap salah

Dengan demikian jumlah sampel pada penulisan ini ditetapkan 100 kuesioner, karena jumlah tersebut telah mencukupi untuk dilakukan pengolahan data.

Keinginan atau harapan karyawan yang teridentifikasi terhadap atribut kualitas layanan pelatihan di Training Centre dapat dilihat pada tabel 1

Tabel 1 Atribut Kepuasan Layanan Yang Diinginkan Karyawan

\begin{tabular}{ccl}
\hline Dimensi & No. & \multicolumn{1}{c}{ Atribut Kepuasan Layanan } \\
\hline & 1 & Fasilitas peralatan ruang kelas materi (LCD, lampu, \\
& 2 & papan tulis, AC, kursi dan meja belajar) \\
& 3 & Fersedianya trainer atau pengajar \\
4 & Tersedianya toilet \\
& 5 & Kebersihan toilet \\
Tangible & 6 & Ruangan pelatihan tidak bising \\
(Berwujud) & 7 & Kebersihan ruang pelatihan \\
& 8 & Kondisi mesin untuk latihan skill baik/ tidak rusak \\
& 9 & Suhu ruangan pelatihan skill nyaman \\
& 10 & Pencahayaan dan sirkulasi udara baik \\
& 11 & Kerapian aset dan tata ruang. \\
& 12 & Penempatan handbook materi di rak sesuai label \\
& 13 & Jumlah mesin yang memadai dalam pelatihan \\
& 14 & Tersedia Instruksi kerja (Showboard) pada tiap exercise \\
\hline
\end{tabular}




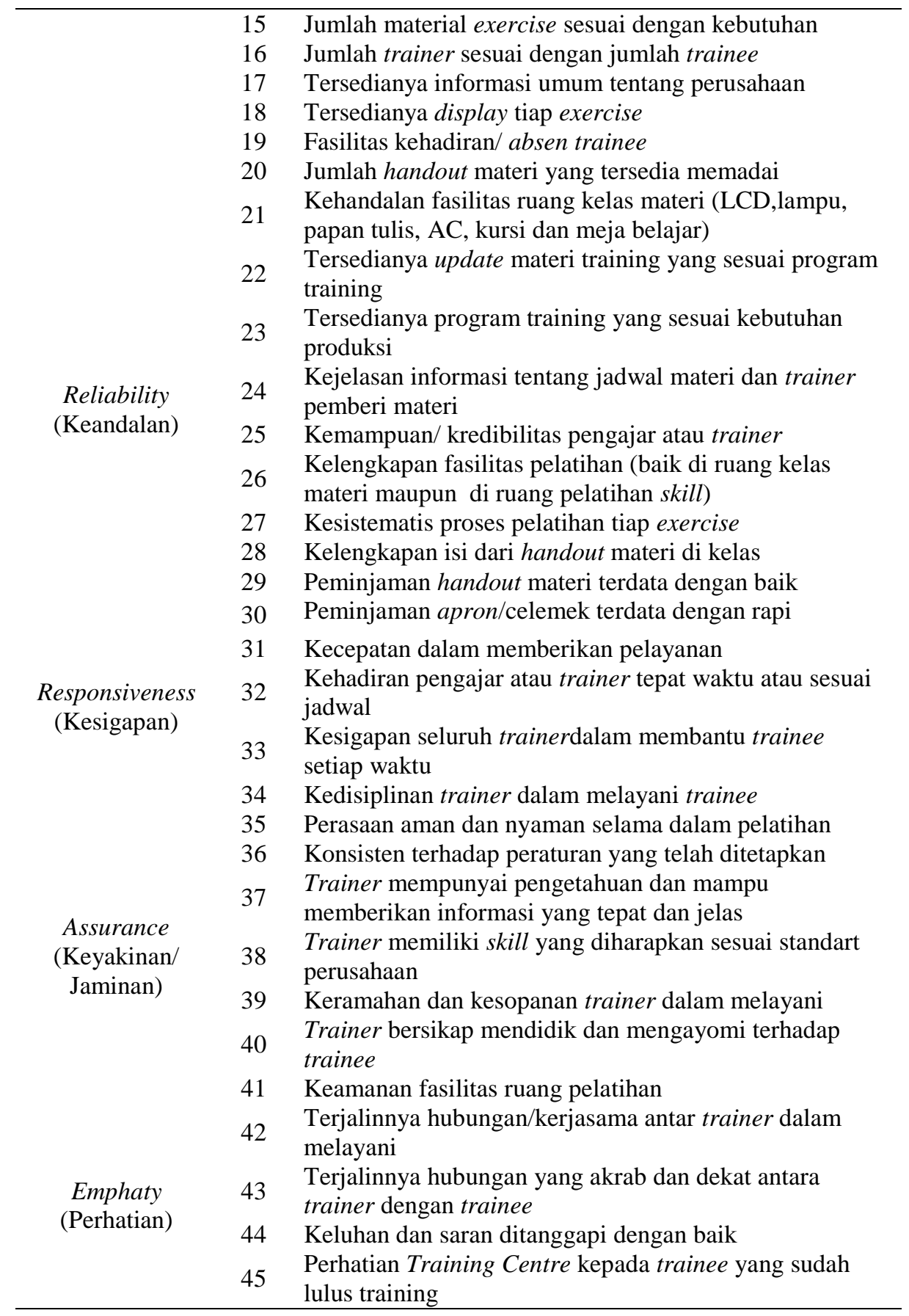

Varibel dinyatakan valid jika nilai rcalculasi $\geq$ rtabel. Dalam hal ini tabel $r$ jika tingkat signifikannya sebesar 5\% dan derajat kebebasanya $\mathrm{df}=\mathrm{n}-2=100-2$ $=98$. Tingkat signifikasi $5 \%$, didapat hasil angka 0 , 1654. Hal ini menunjukkan bahwa data kuesioner yang diperoleh semuanya valid dan dapat digunakan untuk pengolahan data selanjutnya.

Dari hasil uji realibilitas tampak bahwa nilai $\alpha$ untuk masing-masing kuisioner lebih besar daripada $r$ tabel, jadi dapat disimpulkan bahwa kuisioner adalah reliabel.

Berdasarkan perhitungan nilai gap, bahwa dimensi tangible untuk atribut 8 yaitu kondisi mesin Jurnal Teknik Industri, Vol. XI, No. 3, September 2016 untuk latihan skill baik/ tidak rusak memiliki gap terbesar sehingga atribut tersebut harus menjadi prioritas utama dalam perbaikannya.

\section{Penyusunan Rumah Kualitas}

Penyusunan rumah kualitas (HOQ) disini untuk mengetahui atribut-atribut apa saja yang mempengaruhi tingkat pelayanan pada pelatihan yang ada di Training Centre dan untuk mengetahui hubungan antar atribut.

Menentukan Customer Need (WHATs)

Voice Of Customer ini menggambarkan keinginan atau kemauan konsumen terhadap pelayanan yang 
ada saat ini dengan berdasarkan kuisioner yang telah dibuat didapatkan 45 atribut konsumen.

Menentukan Technical Respons (HOWs)

Respon teknis adalah respon yang diberikan oleh perusahaan untuk memenuhi customer needs. Respon teknis ini diperoleh dari hasil wawancara dengan perusahaan. Respon ini diberikan untuk meningkatkan kualitas produk terhadap atribut-atribut yang dipentingkan oleh karyawan.

Pada tahap ini dilakukan pemetaan hubungan antara masing-masing respon teknis untuk mengetahui sejauh mana pengaruh antara masing-masing respon teknis

Menentukan Planning Matrix

Planning Matrix merupakan analisa antara perhitungan yang dilihat dari Training Centre yang nantinya perhitungan itu akan dimasukkan dalam House Of Quality (HOQ).

Importance to Customer (Tingkat Kepentingan)

Perhitungan Importance to Customer dilakukan dengan menjumlahkan data yang terbentuk untuk masing-masing atribut kemudian dibagi dengan jumlah responden yang memberikan penilaian

Customer Satisfaction Performance

Customer Satisfaction Performance merupakan kepuasan karyawan mengenai seberapa baik tingkat pelayanan yang diberikan oleh Training Centre kepada traineenya. Nilai satisfaction performance diperoleh dari performance weight dibagi total responden.

Goal

Dalam pelaksanaannya, nilai goal sama persis dengan nilai expected customer satisfaction.

\section{Improvement Ratio}

Metode yang umum dilakukan dalam menentukan improvement ratio adalah dengan cara membagi goal dengan competitive satisfaction performance.

\section{Sales Point}

Sales point merupakan informasi mengenai kemampuan menjual produk atau jasa berdasarkan seberapa baik setiap customer needs terpenuhi. Nilai yang paling umum untuk sales point adalah : tidak ada titik jual atau jasa, titik penjualan atau jasa menengah dan titik penjualan atau jasa kuat

Raw Weight

Raw weight merupakan suatu nilai yang mengandung importance to customer, improvement ratio, dan sales point.

Normalized Raw Weight

Normalized raw weight adalah nilai raw weight dalam skala 0 sampai 1 yang menunjukkan nilai persentase.

Technical Matrix

Technical matrix merupakan matrik yang dibentuk dari penentuan technical respon.

Priority Technical Respon

Priority technical respon dilakukan dengan menghitung terlebih dahulu kontribusi relatif setiap respon teknis terhadap keseluruhan customer satisfaction

Target

Target merupakan suatu tujuan yang ingin dicapai oleh perusahaan untuk respon teknis yang dimilikinya agar respon teknis perusahaan mampu memenuhi customer needs. Penentuan target disini dapat dilihat hasil perhitungan normalized contribution.

Tabel 2 Respon Teknis (HOWs)

\begin{tabular}{|c|c|}
\hline No. & Respon Teknis \\
\hline 1 & Meningkatkan kecakapan dan kemampuan trainer dalam pelayanan \\
\hline 2 & Meningkatkan keahlian trainer dalam program pelatihan \\
\hline 3 & $\begin{array}{l}\text { Menyediakan kebutuhan pendukung latihan skill buat trainee } \\
\text { (pengajar, materi, mesin, material, dan lain sebagainya) }\end{array}$ \\
\hline 4 & Maintanance mesin dengan melakukan kontrol \\
\hline 5 & $\begin{array}{l}\text { Melakukan update materi dan program training sesuai kebutuhan } \\
\text { produksi }\end{array}$ \\
\hline 6 & Penambahan fasilitas-fasilitas di Training Centre \\
\hline 7 & Menyediakan kotak saran/keluhan dan meresponnya dengan cepat \\
\hline 8 & Trainer meluangkan waktu yang cukup untuk konsultasi \\
\hline 9 & Petugas kebersihan \\
\hline 10 & ruhan pelatihan $\odot$ \\
\hline 11 & i pada peraturan yang tersedia $\bigcirc$ \\
\hline 12 & $\begin{array}{l}\text { Menyederhanakan dan memperjelas semua prosedur di tempat } \\
\text { pelatihan }\end{array}$ \\
\hline
\end{tabular}




\begin{tabular}{|c|c|c|c|c|c|c|c|c|c|c|c|c|c|}
\hline & Customer Requirement & 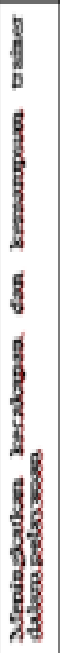 & 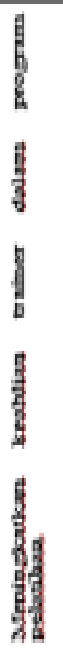 & 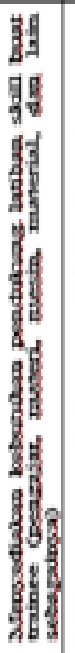 & & 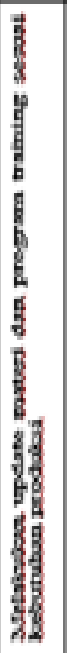 & 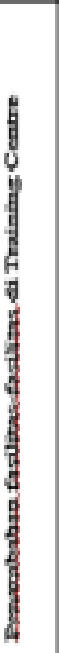 & 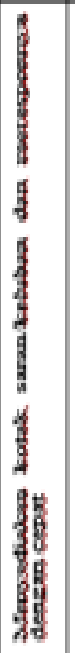 & 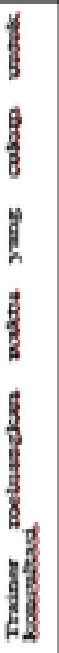 & $\frac{8}{4}$ & $\begin{array}{l}8 \\
8 \\
3 \\
3 \\
3 \\
3\end{array}$ & 8 & 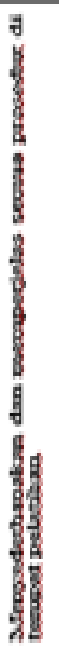 \\
\hline & Solfen & 1 & 1 & 3 & 4 & 6 & 6 & 7 & 8 & 9 & 11 & II & 12 \\
\hline \multirow{20}{*}{ 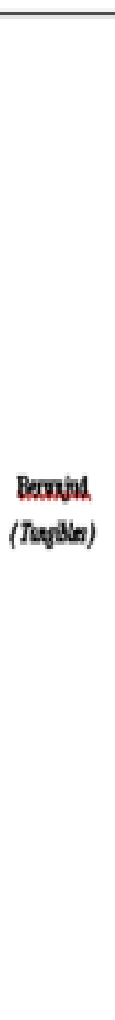 } & 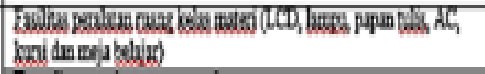 & & & & & & 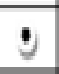 & & & & 0 & $\Delta$ & \\
\hline & 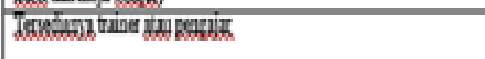 & 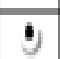 & 4 & & & & & & 0 & & & & \\
\hline & bundasa & & & & & & - & & & $\Delta$ & & & \\
\hline & 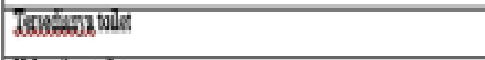 & & & & & & $\dot{3}$ & & & 0 & & & \\
\hline & 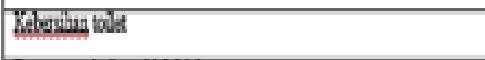 & & & & & & - & & & $\cdot$ & 0 & 0 & \\
\hline & 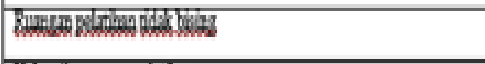 & & & ? & $\dot{9}$ & & & & & & 0 & $\Delta$ & \\
\hline & 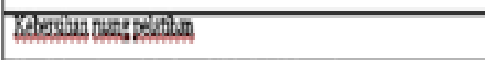 & & & & & & & & & $\bullet$ & 0 & $\cdot$ & \\
\hline & 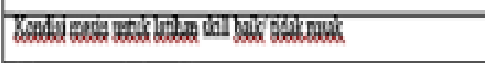 & & 4 & & 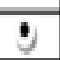 & & & & & & 0 & & \\
\hline & 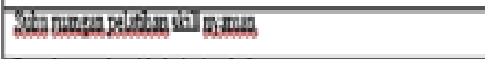 & & & & & & - & & & & 0 & & \\
\hline & 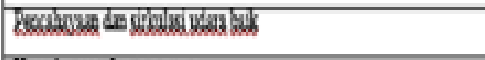 & & & & & & - & & & $\Delta$ & 0 & & \\
\hline & Kaxim & & & & & & 4 & & & $\Delta$ & 0 & & \\
\hline & 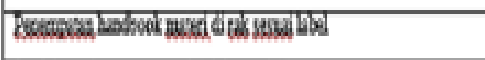 & & & & & & & & & $\Delta$ & 0 & $\bullet$ & \\
\hline & 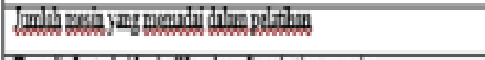 & & & 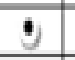 & 0 & & & & & & $\bullet$ & & \\
\hline & 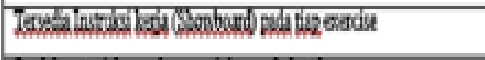 & & & -) & & & $\Delta$ & & & & 0 & & \\
\hline & 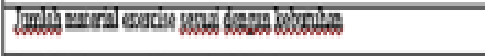 & & & - & & & & & & & $\cdot$ & 0 & \\
\hline & 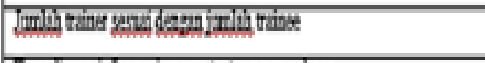 & 0 & $\cdot$ & $\dot{0}$ & & & & & 0 & & & & \\
\hline & 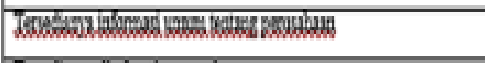 & 0 & & & & & $\dot{0}$ & & & & & & \\
\hline & 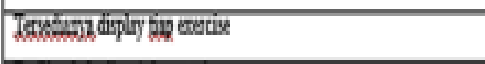 & & & 0 & & & $\dot{0}$ & & & & $\Delta$ & & \\
\hline & 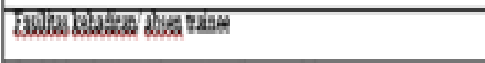 & & & & & & 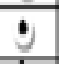 & & & & 0 & & \\
\hline & 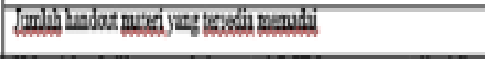 & & & $\theta$ & & $\dot{0}$ & $\Delta$ & & & & 0 & & \\
\hline \multirow{5}{*}{ 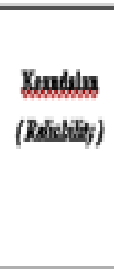 } & 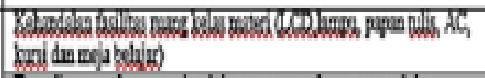 & & & & & & 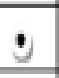 & & & & $\cdot$ & & \\
\hline & 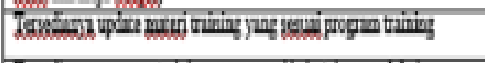 & & • & - & & $\cdot$ & & & & & & & \\
\hline & 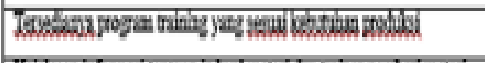 & & - & 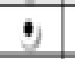 & & $\cdot$ & & & & & & & \\
\hline & 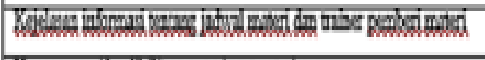 & & & & & & 0 & & & & & & $\cdot$ \\
\hline & 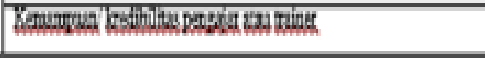 & $\dot{3}$ & $\dot{3}$ & 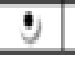 & & & & & 9 & & & & \\
\hline
\end{tabular}

Gambar 3. Menentukan Technical Correlation (Hubungan Antar Matrix HOWs) 


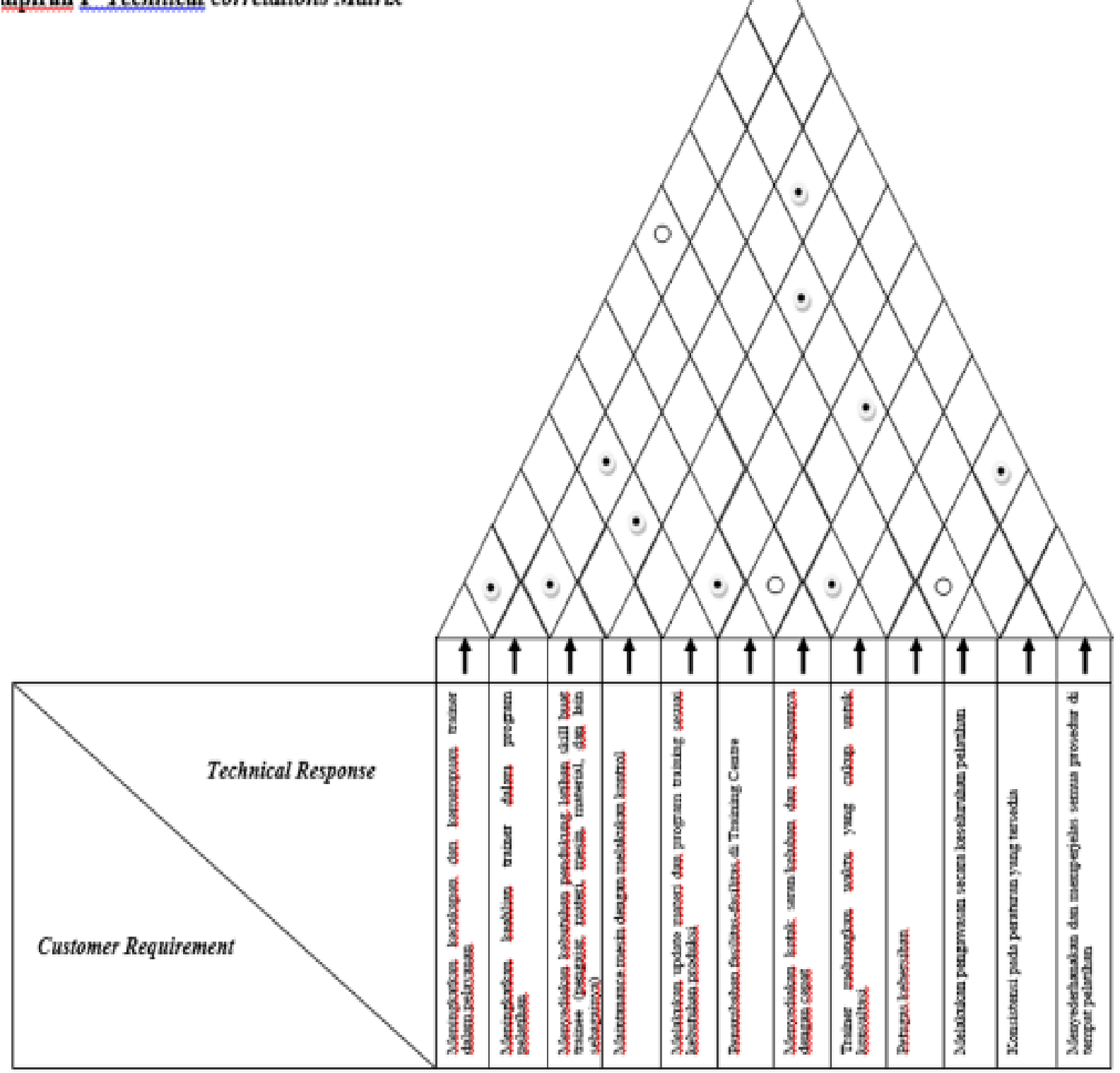

Tabel 3 Hasil Perhitungan Raw Weight

\begin{tabular}{clc}
\hline No. & \multicolumn{1}{c}{ Atribut } & $\begin{array}{c}\text { Raw } \\
\text { Weight }\end{array}$ \\
\hline 1 & Fasilitas peralatan ruang kelas materi (LCD, lampu, & 7.891 \\
2 & papan tulis, AC, kursi dan meja belajar) & 7.759 \\
3 & Tersedianya trainer atau pengajar & 7.617 \\
4 & Tersedianya toilet & 7.834 \\
5 & Kebersihan toilet & 6.085 \\
6 & Ruangan pelatihan tidak bising & 5.928 \\
7 & Kebersihan ruang pelatihan & 5.973 \\
8 & Kondisi mesin untuk latihan skill baik/ tidak rusak & 8.932 \\
9 & Suhu ruangan pelatihan skill nyaman & 5.785 \\
10 & Pencahayaan dan sirkulasi udara baik & 4.705 \\
11 & Kerapian aset dan tata ruang. & 4.604 \\
12 & Penempatan handbook materi di rak sesuai label & 4.712 \\
\hline
\end{tabular}

Jurnal Teknik Industri, Vol. XI, No. 3, September 2016 


\begin{tabular}{|c|c|c|}
\hline 13 & Jumlah mesin yang memadai dalam pelatihan & 8.886 \\
\hline 14 & $\begin{array}{l}\text { Tersedia Instruksi kerja (Showboard) pada tiap } \\
\text { exercise }\end{array}$ & 7.732 \\
\hline 15 & Jumlah material exercise sesuai dengan kebutuhan & 6.446 \\
\hline 16 & Jumlah trainer sesuai dengan jumlah trainee & 6.061 \\
\hline 17 & Tersedianya informasi umum tentang perusahaan & 4.831 \\
\hline 18 & Tersedianya display tiap exercise & 4.644 \\
\hline 19 & Fasilitas kehadiran/ absen trainee & 5.610 \\
\hline 20 & Jumlah handout materi yang tersedia memadai & 4.730 \\
\hline 21 & $\begin{array}{l}\text { Kehandalan fasilitas ruang kelas materi (LCD,lampu, } \\
\text { papan tulis, AC, kursi dan meja belajar) }\end{array}$ & 7.859 \\
\hline 22 & $\begin{array}{l}\text { Tersedianya update materi training yang sesuai } \\
\text { program training }\end{array}$ & 7.314 \\
\hline 23 & $\begin{array}{l}\text { Tersedianya program training yang sesuai kebutuhan } \\
\text { produksi }\end{array}$ & 7.432 \\
\hline 24 & $\begin{array}{l}\text { Kejelasan informasi tentang jadwal materi dan } \\
\text { trainer pemberi materi }\end{array}$ & 4.615 \\
\hline 25 & Kemampuan/ kredibilitas pengajar atau trainer & 7.419 \\
\hline 26 & $\begin{array}{l}\text { Kelengkapan fasilitas pelatihan (baik di ruang kelas } \\
\text { materi maupun di ruang pelatihan skill) }\end{array}$ & 7.576 \\
\hline 27 & Kesistematis proses pelatihan tiap exercise & 5.517 \\
\hline 28 & Kelengkapan isi dari handout materi di kelas & 4.634 \\
\hline 29 & Peminjaman handout materi terdata dengan baik & 4.496 \\
\hline 30 & Peminjaman apron/celemek terdata dengan rapi & 5.501 \\
\hline 31 & Kecepatan dalam memberikan pelayanan & 6.226 \\
\hline 32 & $\begin{array}{l}\text { Kehadiran pengajar atau trainer tepat waktu atau } \\
\text { sesuai jadwal }\end{array}$ & 6.052 \\
\hline 33 & $\begin{array}{l}\text { Kesigapan seluruh trainer dalam membantu trainee } \\
\text { setiap waktu }\end{array}$ & 7.937 \\
\hline 34 & Kedisiplinan trainer dalam melayani trainee & 5.751 \\
\hline 35 & Perasaan aman dan nyaman selama dalam pelatihan & 5.929 \\
\hline 36 & Konsisten terhadap peraturan yang telah ditetapkan & 5.680 \\
\hline 37 & $\begin{array}{l}\text { Trainer mempunyai pengetahuan dan mampu } \\
\text { memberikan informasi yang tepat dan jelas }\end{array}$ & 7.713 \\
\hline 38 & $\begin{array}{l}\text { Trainer memiliki skill yang diharapkan sesuai } \\
\text { standart perusahaan }\end{array}$ & 7.743 \\
\hline 39 & Keramahan dan kesopanan trainer dalam melayani & 5.916 \\
\hline 40 & $\begin{array}{l}\text { Trainer bersikap mendidik dan mengayomi terhadap } \\
\text { trainee }\end{array}$ & 7.441 \\
\hline 41 & Keamanan fasilitas ruang pelatihan & 5.746 \\
\hline 42 & $\begin{array}{l}\text { Terjalinnya hubungan/kerjasama antar trainer dalam } \\
\text { melayani }\end{array}$ & 7.382 \\
\hline 43 & $\begin{array}{l}\text { Terjalinnya hubungan yang akrab dan dekat antara } \\
\text { trainer dengan trainee }\end{array}$ & 7.136 \\
\hline 44 & Keluhan dan saran ditanggapi dengan baik & 5.788 \\
\hline 45 & $\begin{array}{l}\text { Perhatian Training Centre kepada trainee yang sudah } \\
\text { lulus training }\end{array}$ & 5.552 \\
\hline
\end{tabular}

\section{Kesimpulan}

Atribut pelayanan kualitas jasa pelatihan berdasarkan lima dimensi Servqual sebanyak 45 atribut. Diantara faktor bukti langsung (tangibles), keandalan (reliability), daya tanggap (responsiveness), jaminan (assurance), dan empati (empathy) yang disediakan oleh pihak Training Centre, pada dimensi bukti langsung (tangibles), merupakan faktor yang memiliki atribut tertinggi

Jurnal Teknik Industri, Vol. XI, No. 3, September 2016 yaitu 20 atribut yang mempengaruhi kepuasan karyawan pada pelatihan di Training Centre.

Dari hasil analisis Service Quality (analisa gap) yang dilakukan berdasarkan persepsi dan harapan karyawan, dapat diketahui bahwa karyawan di PT. XYZ yang pernah mengikuti pelatihan di tahun 2014 menilai pelayanan yang dilakukan pihak Training Centre belum sesuai dengan apa yang diharapkan oleh karyawan tersebut. Hal ini ditunjukkan dalam analisis gap berdasarkan hasil kuesioner bahwa 
seluruh atribut yang ada yaitu sebanyak 45 atribut memiliki nilai gap negatif. Rangking pertama yang memiliki nilai gap terbesar adalah kondisi mesin untuk latihan skill baik/ tidak rusak.

Berdasarkan rumah kualitas dan analisa sesuai dengan metode yang telah ditentukan, maka perbaikan sistem yang didapatkan adalah sebagai berikut :

a. Kualitas pada Training Centre yang ada saat ini kurang memuaskan jika dibandingkan dengan apa yang diharapkan oleh para konsumennya. Sesuai analisa prioritas raw weight maka diketahui atribut-atribut yang perlu diperhatikan berdasarkan 3 ( tiga ) prioritas utama sebagai berikut :

1. Kondisi mesin untuk latihan skill baik/ tidak rusak dengan nilai prioritas raw weight $(8,932)$

2. Jumlah mesin yang memadai dalam pelatihan dengan nilai prioritas raw weight ( 8,886)

3. Kesigapan seluruh trainer dalam membantu trainee setiap waktu dengan nilai prioritas raw weights $(7,937)$

b. Prioritas pelayanan yang sangat membutuhkan perhatian lebih dari pihak Training Centre untuk segera diperbaiki berdasarkan 3 (tiga) prioritas respon teknis adalah

1. Melakukan pengawasan secara keseluruhan pelatihan dengan nilai ( 0,184$)$

2. Meningkatkan keahlian trainer dalam program pelatihan dengan nilai $(0,137)$

3. Penambahan fasilitas-fasilitas di Training Centre dengan nilai ( 0,129$)$

\section{Daftar Pustaka}

Wurjaningrum, Febriana, 2010, Penerapan Model Quality Function Deployment (Qfd) Untuk Merancang Perbaikan Kualitas Layanan Pendidikan Pada Universitas Airlangga, Majalah Ekonomi, Tahun XX, No. 2 Agustus 2010.

Frida, Myrna, dkk, 2011, Peningkatan Kualitas Layanan Harian Sore Surabaya Post Dengan Pendekatan Service Quality (Serqual) Dan Quality Function Deployment (Qfd), Institut Teknologi Sepuluh November Surabaya.
Dwiwinarsih, Rina, 2009, Analisis Tingkat Kepuasan Konsumen Terhadap Pelayanan Bakmi Aisy Di Depok, Jurnal Ekonomi Manajemen, Oktober 2009.

Ginting, Meriastuti; Halim, Deasy Indriyani, 2012, Usaha Peningkatan Kualitas Pelayanan Perpustakaan Ukrida Dengan Metode Serqual Dan Quality Function Deployment (QFD), Jurnal Teknik Dan Ilmu Komputer Vol.01 No.2, Apr-Jun 2012.

Handoko, Tan, J Sudarsono, 2013, Pengaruh Marketing Stimuli Dan Service Quality Terhadap Kepuasan Pelanggan Dan Efeknya Pada Word Of Mouth.

Imron, Bukhari, 2014,Rancangan Produk Charger Handphone Portable Dengan Metode Quality Function Deployment (QFD). Jurnal Online Institut Teknologi Nasional, No. 2, Vol.2, April 2014.

Megawati, Yenli, 2006, Kualitas Pelayanan Terkait Dengan Kepuasan Konsumen Dalam Industri Jasa Business Dan Management Journal Bunda Mulia, Vol.2, No.1, September 2006.

Sriwidodo, Untung; Indriastuti, Rully Tri, 2010, Pengaruh Dimensi Kualitas Pelayanan Jasa Terhadap Kepuasan Nasabah. Jurnal Ekonomi Dan Kewirausahaan, Vol.10, No.2, Oktober 2010, 164-173.

Suharyati, Ruth, dkk, 2013, Pengaruh Kualitas Produk Dan Harga Terhadap Kepuasan Konsumen Pada PT. Nyonya Meneer Semarang (Studi Kasus Pada Konsumen Jamu Habis Bersalin).

Wijaya, Tony,2011, Manajemen Kualitas Jasa, PT. Indeks, Jakarta.

Marliana, Sonya; Dharmastiti, Rini, 2008, Integrasi Servqual Dan QFD Untuk Meningkatkan Kualitas Layanan Angkutan Massa Trans Jogja, Seminar Nasional Aplikasi Sains Dan Teknologi 2008, IST AKPRIND Yogyakarta. Wahyuni, Hana Catur; Sulistyowati, Wiwik, 2015, Penentuan Prioritas Perbaikan Kualitas Layanan Kesehatan Dengan Metode Serqual, Jemis Vol.3 No.1, 2015 